\title{
Development of research on nursing diagnoses in Brazilian graduate programs
}

\author{
Desenvolvimento da pesquisa sobre diagnósticos de enfermagem nos programas de pós-graduação brasileiros \\ Desarrollo de la investigación sobre diagnósticos de enfermería en los programas de posgrado brasileños
}

\author{
Gisele Saraiva Bispo Hirano' \\ ORCID: 0000-0001-6649-8778 \\ Camila Takáo Lopes' \\ ORCID: 0000-0002-6243-6497
}

Alba Lucia Bottura Leite de Barros'

ORCID: 0000-0003-2691-3492

'Universidade Federal de São Paulo. São Paulo, São Paulo, Brazil.

How to cite this article:

Hirano GSB, Lopes CT, Barros ALBL. Development of research on nursing diagnoses in Brazilian graduate programs. Rev Bras Enferm. 2019;72(4):926-32. doi: http://dx.doi.org/10.1590/0034-7167-2018-0259

Corresponding Author:

Gisele Saraiva Bispo Hirano

E-mail: giselesabi@hotmail.com

Submission: 04-24-2018

Approval: 08-18-2018

\section{ABSTRACT}

Objective: to characterize the development of research on nursing diagnoses in nursing graduate programs and verify the application of the results of these studies according to the perception of academic advisors. Methods: documental research on dissertations and theses available from the databases of Brazilian universities with graduate programs in nursing, and exploratory survey on the practical application of their results. Results: 216 dissertations and theses were analyzed. Most of them were descriptive studies, and the most widely used diagnostic taxonomy was NANDA International. Little practical use of the knowledge produced by the dissertations and theses was identified. Conclusion: Although there has been a considerable increase in research on nursing diagnoses, the survey stage revealed scarce practical application of their results, prompting the need for further studies in order to identify the barriers in the way of transposing theory to practice.

Descriptors: Nursing Diagnosis; Nursing Education; Nursing Research; Standardized Nursing Terminology; Graduate Nursing Education.

\section{RESUMO}

Objetivo: Caracterizar o desenvolvimento das pesquisas sobre diagnósticos de enfermagem nos programas de pós-graduação em enfermagem brasileiros e verificar a aplicação dos resultados desses estudos de acordo com a percepção dos orientadores. Métodos: Pesquisa documental nos bancos eletrônicos de dissertações e teses de universidades brasileiras com programas de pós-graduação em enfermagem e survey exploratório sobre a aplicação prática dos resultados. Resultados: Foram analisadas 216 dissertações e teses. A maioria tratava-se de estudos descritivos, sendo a taxonomia diagnóstica mais utilizada a NANDA International. Identificou-se pouca utilização prática do conhecimento produzido pelas dissertações e teses sobre a temática em questão. Conclusão: Embora tenha revelado aumento considerável nas pesquisas sobre diagnósticos de enfermagem, a fase de survey revelou pouca aplicação prática dos resultados obtidos, o que sugere a realização de novos estudos no intuito de identificar as barreiras para que ocorra a transposição da teoria para a prática.

Descritores: Diagnósticos de Enfermagem; Educação em Enfermagem; Pesquisa em Enfermagem; Terminologia Padronizada em Enfermagem; Educação de Pós-Graduação em Enfermagem.

\section{RESUMEN}

Objetivo: caracterizar el desarrollo de las investigaciones sobre diagnósticos de enfermería en los programas de postgrado en enfermería brasileños y verificar la aplicación de los resultados de esos estudios de acuerdo con la percepción de los orientadores. Métodos: investigación documental en los bancos electrónicos de disertaciones y tesis de universidades brasileñas con programas de postgrado en enfermería y survey exploratorio sobre la aplicación práctica de los resultados. Resultados: se analizaron 216 disertaciones y tesis. La mayoría se trataba de estudios descriptivos y la taxonomía diagnóstica más utilizada fue NANDA International. Se identificó poca utilización práctica del conocimiento producido por las disertaciones y tesis sobre la temática en cuestión. Conclusión: Aunque se ha revelado un aumento considerable en las investigaciones sobre diagnósticos de enfermería, la fase de survey reveló poca aplicación práctica de los resultados obtenidos, lo que sugiere la realización de nuevos estudios con el fin de identificar las barreras para que ocurra la transposición de la teoría para la práctica.

Descriptores: Diagnóstico de Enfermería; Educación en Enfermería; Investigación en Enfermería; Terminología Normalizada de Enfermería; Educación de Post Grado em Enfermería. 


\section{INTRODUCTION}

With the increasing computerization of medical records, the use of a single diagnostic language is both inevitable and essential, in order standardize nursing documental resources and enable comparisons and assessment of the effectiveness of interventions in solving certain health problems, as well as facilitate the research on the prevalence of nursing diagnoses (NDs) in specific populations ${ }^{(1)}$.

Over the years, research involving the analysis of diagnostic languages, seeking their scientific validation, has had a growing importance in the work of nursing graduate students. This research is done according to a variety of study designs. The accelerated growth of nursing graduate programs (Programas de Pós-graduação em Enfermagem, PPGE) since they first appeared in the 1970s has been accompanied, especially in the last 20 years, by an exponential growth of scientific production in the area, including research on NDs. Moreover, in addition to a higher number of studies, over time a considerable increase in the quality of the developed researches can be observed ${ }^{(2)}$.

An unpublished preliminary study, carried out for oral presentation at the 12th National Symposium on Nursing Diagnoses, analyzed the production on NDs by Brazilian nursing graduate courses during the 2011-2015 period. Involving researchers who study this theme, it investigated the translation of theoretical knowledge to daily health practice ${ }^{(3)}$. The study made it possible to identify various methods for ND study, the use of different nursing theories - like those by Orem and Wanda Horta-as well as the transposition of knowledge on the subject to the professional practice of nurses in different areas of expertise.

Given the importance of standardized nursing languages, here we sought to extend the aforementioned search to other nursing graduate courses not included in the preliminary study, expanding the search period, in order to more clearly express the production in this scientific area, and identify if and how this knowledge has been put into practice.

Silva et al. ${ }^{(4)}$ carried out a similar study and identified a significant amount of graduate course research on NDs. Silva's research shows that dissertations and theses (DTs) on the subject have focused on identifying diagnostic profiles or on content validation; it also shows that the most commonly employed diagnostic classification is NANDA-I.

In both of the previously mentioned studies, there were no analyses of studies' target populations, or of the locations where their research results had greater practical application. Even though Silva et al. ${ }^{(4)}$ were able to categorize the analyzed theses and dissertations into large thematical areas (women's health, adult and elderly health, etc.), a large gap of knowledge on the practical application of the analyzed studies remains.

\section{OBJECTIVES}

To characterize the current research on standardized nursing diagnostic languages by Brazilian graduate nursing courses, and verify the application of the results of these studies according to the perception of academic advisors.

\section{METHODS}

\section{Ethical aspects}

This study was approved by the Research Ethics Committee of the Federal University of São Paulo.

\section{Study design, location and period}

This is a descriptive-exploratory research, held at the Nursing School of the Federal University of São Paulo (Escola Paulista de Enfermagem da Universidade Federal de São Paulo) between 2016 and 2017. It was comprised of two phases: Phase 1 - documental research and phase 2 - exploratory survey.

\section{Study sample, inclusion and exclusion criteria}

In the first phase of the study, the sample was comprised of theses and dissertations defended in Brazilian nursing graduate programs. It included theses and dissertations defended from 2006 to 2016; these studies analyzed nursing diagnoses separately or in conjunction with interventions and results.

In the second phase of the study, the sample consisted of academic advisors of theses and dissertations on nursing diagnoses defended from 2006 to 2016. Those who failed to answer to our questionnaire after 10 days were excluded from the sample.

\section{Study protocol}

- First phase: Documental research

The list of academic or professional master's and doctorate courses in Brazilian higher education institutions (HEls) was obtained directly from CAPES (Coordination for the Improvement of Higher Education Personnel). Next, three steps were carried out:

1st step: Search in the electronic repositories of the included $\mathrm{HEl}$. An attempt was made to access digital databases of theses and dissertations of $61 \mathrm{HEls}$ between September 2016 and February 2017. Three universities did not have electronic databases for theses and dissertations, or the database was unavailable during the search period. Thus, 58 electronic databases were accessed and searched for studies defended during the period from January 2006 to December 2016, with title and/or keywords containing the terms "nursing diagnosis" or "nursing diagnoses."

2nd step: Requests for unavailable studies. The lead researcher sent emails to the authors of the selected dissertations and theses, explaining the goals of the study and requesting unavailable studies to be submitted electronically. After three weeks a reminder was sent to those who had not responded to the first email; they were given one more week to answer.

3rd step: Survey of advisors' Lattes Curricula. The Lattes Curricula of advisors of searched studies was verified so as to check for other dissertations and theses carried out in the same period but for some reason not available from the digital databases. This search aimed to include as much works as possible in the analysis, reducing limitations due to the likelihood of certain databases being out of date. DTs identified via Lattes curricula that were not located through searching the digital databases were subsequently requested directly to their authors. 
After finding the DTs, we proceeded to the reading them in full, in order to identify the following data: HEl where the study was carried out, methodology, standardized languages employed, domains to which the nursing diagnoses belonged (in the case of NANDA-INDs), focus population of the study (clinical situation and age group), nursing theories addressed, theoretical and methodological references (when mentioned), in addition to the lines of research followed by the studies (as described by the authors themselves).

When DTs performed the analysis of more than one ND, up to five NDs were listed in full. When this number was exceeded, as in studies aiming at the elaboration of diagnostic profiles, the study was assigned the tag "multiple diagnoses," in order to facilitate the grouping of the mentioned NDs.

When the study did not discuss or analyze any specific diagnosis-discussing, for instance, the construction of tools to facilitate ND identification and clinical reasoning ${ }^{(5-6)}$, or software development to facilitate the teaching/learning process of diagnostics ${ }^{(7)}$ - the diagnosis was classified as "ignored," for analytical purposes.

We considered as theoretical referentials specific (nursing or otherwise) theories or models used to support the study's discussion, execution and/or data analysis.

\section{- Second phase: Exploratory survey}

After project approval by the Ethics Committee, an informed consent form and a questionnaire were sent electronically to researchers identified as advisors of DTs selected during the first phase.

The questionnaire was made up of issues related to the identity of the researcher, their participation in research groups, and their perception on the practical application of the knowledge generated by their research group and its graduates for teaching, research, health care and nursing policy.

The advisors were asked to answer the following question: "Considering the production of knowledge on nursing diagnoses generated by your study and research group in the last 10 years, mark on Likert Scale how it has been used by yourself and by your graduate students."The answers about the practical application of knowledge on NDs were displayed on the four-point Likert Scale (0: I do not know, 1: Very little practical use; 2: Little practical use; 3: Frequent practical use; 4 : A lot of practical use). The advisor was only accepted for inclusion in this study after returning the Likert questionnaire and the informed consent form, both properly filled.

After three weeks a reminder was sent to those who had not responded to the first email; they were given one more week to answer.

\section{Analysis of results and statistics}

The data were prepared in MS Office Excel ${ }^{\circledR}$ spreadsheets, 2013 version. DTs were analyzed by means of descriptive statistics. For the analysis of answers from researchers, absolute $(n)$ and relative (\%) frequencies were used, as well as the weighted average for each item of the questionnaire (sum of the weights assigned to each answer divided by the total number of answers). For this calculation, the following weights were considered: $0=0 ; 1=0.25$; $2=0.5 ; 3=0.75 ; 4=1$. From the obtained values, items that had a weighted average greater than or equal to 0.75 were considered "high profile" while those with less than 0.75 were labeled as having "low profile."

\section{RESULTS}

In the first phase of the study, only 30 databases contained DTs suiting the defined criteria. Two hundred and twenty-four DTs were located, however only 216 (96\%) were fully accessible: There were 163 (75\%) master's dissertations (153 academical master's, and 10 professional master's) and 53 (25\%) doctoral theses.

Studies not fully accessible $(n=8)$ were master's dissertations: three from 2016 and one from each of the following years: 2006, 2008, 2012, 2013, and 2015. In two cases we were unable to find the corresponding author's email, in one case, the author's email was non-existent, and in the other cases, the authors did not respond to requests.

With respect to the studies' periods of publication, only 6 were from 2006, while 26 studies from 2016 were identified, an increase of more than $400 \%$. The highest number of studies were from 2014, with 31, amounting to $517 \%$ more than the number of studies from 2006 (Figure 1).

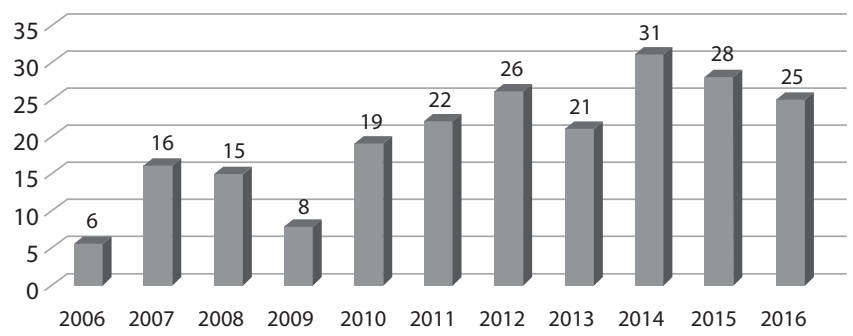

Figure 1 - Number of dissertations and theses on Nursing Diagnoses by Brazilian nursing graduate programs, 2006 to 2016

A great variety of methods for the development of studies was identified. Predominant methods were descriptive research $(n=79 ; 36 \%)$, followed by methodological research ( $n$ $=57 ; 26 \%)$ and descriptive-exploratory research ( $n=32 ; 15 \%)$. Randomized clinical assays represented only $1 \%(n=3)$ of the analyzed studies.

The most used standardized language was the NANDA-I ( $n=$ $183,85 \%)$, followed by the ICNP ( $n=26,12 \%)$. However, seven ( $3 \%$ ) DTs did not declare which standardized language they employed; these were tagged as having "no description." Seventy-three (73) distinct NANDA-I NDs were investigated by the studies. The more frequently studied domain was Safety/Protection. Forty-eight (48) studies investigated multiple diagnoses. In 16 DTs, the diagnosis was classified as ignored, because the authors did not analyze any specific ND. This was the case, for example, for works on diagnostic reasoning or software development.

Table 1 presents the distribution of NANDA-I NDs per classificatory domain.

With regard to studies which employed the ICNP ${ }^{\circledR}$ diagnostic language, we observed as predominant traits the creation of new catalogues or terminological subsets ( $n=11 ; 40.7 \%$ ), followed by studies which developed diagnostic profiles of specific populations ( $n=9 ; 33.3 \%$ ). Diagnoses of Anxiety and Fear were mentioned one time each. Four DTs mentioned no specific diagnoses, and thus received the "ignored" tag. 
Table 1 - NANDA-I domains present in dissertations and theses on nursing diagnoses, 2006 to 2016

\begin{tabular}{lcc}
\hline NANDA-I Domains & Mentions (n) & $\%$ \\
\hline Domain 1. Health promotion & 13 & 6.6 \\
Domain 2. Nutrition & 12 & 6.1 \\
Domain 3. Elimination and Exchange & 9 & 4.6 \\
Domain 4. Activity/Rest & 26 & 13.2 \\
Domain 5. Perception/Cognition & 7 & 3.6 \\
Domain 6. Self-perception & 1 & 0.5 \\
Domain 7. Role relationship & 2 & 1.0 \\
Domain 8. Sexuality & 1 & 0.5 \\
Domain 9. Coping/Stress tolerance & 3 & 1.5 \\
Domain 10. Life Principles & 2 & 1.0 \\
Domain 11. Safety/Protection & 43 & 21.8 \\
Domain 12. Comfort & 10 & 5.1 \\
Domain 13. Growth/Development & 4 & 2.0 \\
Ignored & 16 & 8.1 \\
Multiple Domains & 48 & 24.4 \\
\hline
\end{tabular}

With respect to the characteristics of the studied populations, most research focused on the adult population ( $n=129 ; 60 \%)$ and individuals with clinical disorders $(n=101 ; 47 \%)$. The child population was studied in 32 papers $(15 \%)$, while the elderly population was the focus of 19 papers (9\%). In 27 studies (12\%), the population focus was not specified by the author.

In 33 studies (17\%), the authors mentioned theoretical references from the field of nursing and also from other areas. In some cases, more than one reference was mentioned (Table 2). In terms of DTs that made reference to nursing theories, most resorted to the theory as a basis for the development of instruments of data collection and analysis. However, in some cases, we noted that, although the theory had been cited as guidance for the research, it was scarcely used in the discussion of the obtained results.

Terms such as "theoretical milestone" (marco teórico) and "theoretical framework" (referencial teórico) were used interchangeably by many authors. Often, the theoretical framework was a cornucopia of existing research on the subject, almost like a literature review. In other studies, the section dealing with the theoretical framework explained and detailed a particular theory that had been used to support data collection or discussion of results.

Out of 92 DT advisors contacted in phase 2 of this study, 30 (33\%) responded to the questionnaire. Participating researchers were from 17 different HEls and 12 of them (40\%) were researchers for the National Council for Scientific and Technological Development (CNPq), in addition to other research agencies. Only 25 researchers responded to the question about the diagnostic taxonomy used in their research; $76 \%$ $(n=19)$ referred to the use of NANDA-I, 20\% $(n=5)$ reported using both NANDA-I and ICNP ${ }^{\circledR}$, while $4 \%(n=1)$ reported using only ICNP ${ }^{\circledR}$.
Table 2 - Theoretical references mentioned by authors of dissertations and theses on nursing diagnoses, 2006-2016 ( $\mathrm{N}=33)$

Theoretical frameworks

Mentions

(n)

Theory of Basic Human Needs (Horta, 1979)

Adaptation Model (Roy, 2001) 4

Problem-based learning 2

Bio-ecology of human development (Bronfenbrenner, 1996) 2

Theory of social representations (Moscovici, 1978) 2

Theory of self-care (Orem, 1991)

Model of clinical reasoning (Risner, 1986)

Holistic conception (Fritjof Capra, 1983)

V Diagram (Moreira, 2007)

Developing life stories

Symbolic interactionism (Blumer, 1969)

Calgary Family Assessment Model (Wright, 2002)

Critical Thinking (Bittencourt, 2011)

Special needs of childhood (Brazelton; Greespan, 2002)

Fundamental standards of knowledge in nursing (Carper, 1978)

Complex thinking (Edgar Morin, 2007)

Evidence-based practice

Learning process of the individual (McLennan; Anderson; Pain, 1996)

Psychometrics (Pasquali, 1998)

Learning theory

Theory of human becoming (Parse, 1981)

Theory of goal attainment (King, 1981)

Theory of comfort (Kolcaba, 2003)

Fuzzy sets theory (Zadeh, 1965)

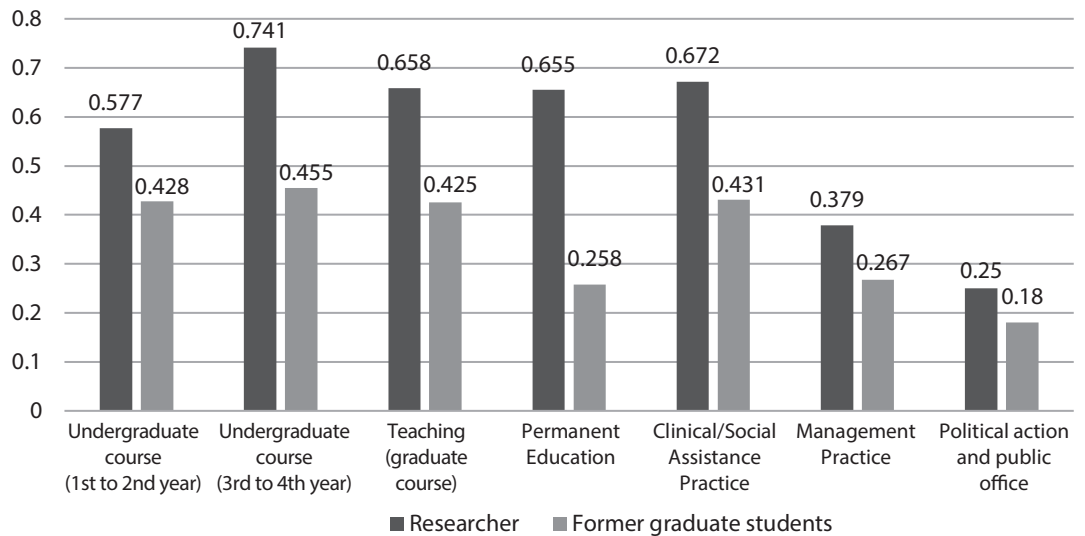

Figure 2 - Weighted averages of researchers' answers regarding the practical application of knowledge about nursing diagnoses generated by their research groups, 2006-2016.

Weighted averages of answers from advisors regarding the practical application of the results of their studies in their or their graduates' professional lives can be found in Figure 2.

Researchers reported a greater use of knowledge about NDs from the 3 rd to the 4 th year of the undergraduate nursing course, but the weighted average of the responses remained in the low profile classification (0.74). Since the weighted averages were lower than 0.75 for all scenarios, the application of results by researchers and their graduates was considered "low profile." 


\section{DISCUSSION}

This study characterized the development of research on standardized nursing diagnostic languages by Brazilian graduate nursing courses, and verified the application of these studies' results.

We found that the research production on NDs grew considerably in the last decade. According to Benedet et al. ${ }^{(8)}$, the expressive growth of scientific literature about NDs after the 1990s came about mainly with the publication in Portuguese of the book "Nursing diagnosis: a conceptual and practical approach" (Diagnóstico de Enfermagem: uma abordagem conceitual e prática). The same authors, when analyzing the production of the Brazilian Journal of Nursing, identified that, at the beginning of 2003, the number of published research articles on NDs was significantly lower than in 2010.

Corroborating these data, a study identified that, in the first decades after the emergences of the term "Nursing Diagnostics", researches by Brazilian nursing graduate courses on this topic were sparse or nonexistent. In the 1990s and 2000s, the academic production on this topic became a relevant feature of the nursing research space ${ }^{(4)}$.

With respect to the methodologies used for the development of DTs, observational methods of the descriptive and descriptive/ exploratory type are still predominant, to the detriment of studies with a higher level of scientific evidentiary support, such as clinical trials (whether randomized or not).

Although scientific research, when well executed, produces important results in the intended area regardless of the adopted method, clinical trials produce scientific knowledge that can lead to new technologies for health, contributing to evidence-based practices, as well as to increasing the evidentiary support for diagnoses of the NANDA-I classification and the ICNP catalogues. However, clinical research in nursing is still a novel area, and properly randomized clinical trials are still a minority, especially since studies of this type require more time and entail a higher cost when compared to observational studies, and this can be a determining factor of their low occurrence ${ }^{(9)}$.

Methodological studies also had good representation among DTs, involving, most of the time, the purposes of validating NDs, defining their characteristics, as well as interventions or conceptual analysis. This type of research involves the investigation of methods to collect and organize data and perform rigorous research addressing the development, validation and evaluation of research tools and methods, and has been widely used in nursing because of the growing demand for evaluations of results, in order to assess their solidity and trustworthiness ${ }^{(10)}$.

Although complex, ND validation studies of existing diagnoses or new diagnostic proposals contribute greatly to the field of nursing. In questioning whether a diagnostic is valid, one aims to determine if it was identified appropriately, excluding others that share the same characteristics. Another goal of diagnostic validation is to determine if the obtained data are represented with accuracy, i.e., to find out whether the diagnosis effectively represents patients' behaviors and characteristics ${ }^{(11)}$.

To propose a new ND is a complex activity that requires knowledge of clinical practice. According to Carpenito-Moyet ${ }^{(12)}$, this process is difficult because nurses have to try and diagnose human responses, and since human beings are unique and complex beings who are always undergoing change, attempts at classification of these responses are laborious.

In this study, we identified that the main standardized language for the classification of NDs was the NANDA-I, followed by the ICNP ${ }^{\circledR}$. This result confirms the findings of other authors ${ }^{(4-9)}$. ICNP ${ }^{\circledR}$, like NANDA-I, is a classification created in the late 1980s; it went through several revisions and adjustments, increasing its presence in ND studies with standardized languages throughout the years.

Studies using the NANDA-I classification consisted mostly in the elaboration of diagnostic profiles for specific populations, while studies using the ICNP ${ }^{\circledR}$ classification consisted mostly in the creation of catalogs/terminological subsets. We believe the data reveal the interest of nurse researchers to acquire knowledge on the human responses of specific populations, so as to provide a more adequate assistance.

This kind of study favors the development of data collection instruments ${ }^{(10)}$, establishes basis for the creation of customer service protocols ${ }^{(13)}$ and the identification of priority nursing actions, in addition to providing data for the appropriate planning of assistance, since it offers subsidies for the implementation of the nursing process in institutions ${ }^{(14)}$. It is known that, although the law requires the execution of the nursing process in all environments where there is a professional nursing practice, in reality there are many difficulties in its proper implementation and enforcement, with the diagnostic phase being the one where nurses encounter the greatest difficulties ${ }^{(15)}$.

The most present domain in studies with NANDA-I NDs was domain 11, which involves diagnoses related to the safety and protection of the individual, family or community, while domains involving self-perception and sexuality were present in only one study, suggesting the need for more research in graduate nursing programs with NDs in these domains, so they can be refined to better reflect reality.

In analyzing the studied populations, the predominance of the adult population is obvious. However, a significant amount of research focused on the pediatric population as a whole (newborns, infants and children). This population has its particularities and specific needs, and the interest in improving the assistance provided to it is very important.

DTs which studied NDs in the pediatric population had several objectives, including the preparation of protocols for the care of children with specific conditions ${ }^{(16)}$, analysis of child development $^{(17)}$, among others. We believe that research of this type, along with several other measures, contribute to the prevention of diseases and improvement in the quality of care provided to the pediatric population. There have been several advances in pediatric health care. A proof of that is the fact that, in the last decade, Brazil has achieved the goal set by the United Nations for the reduction of child mortality ${ }^{(18)}$.

The elderly population had little representativity in the studies. This is paradoxical, considering the proportion of elderly in the Brazilian population is around $13 \%$ and increasing ${ }^{(19)}$. Most DTs, while studying NDs in the adult population, generally included the elderly; they were not, however, the focus of these studies. Only in a few cases the study of the NDs was devoted specifically to this population. Studies on NDs present in the elderly 
population in general, as well as the validation of NDs in this specific population, are an indispensable basis for nursing care.

With respect to the data obtained in the second phase of this study, we found that, according to the perception of graduate nursing program advisors, research results have had little practical application. In respect to nursing graduates from these programs, we found there is an even smaller use of this knowledge. However, one should note that, in this regard, the averages may not fully reflect reality, since the advisor's knowledge on the activities of his/ her graduates may not correspond to what is actually taking place.

Graduate courses tend to inspire students/graduates to mobilize scientific knowledge during their daily practice, changing the way they see the world around them, and encouraging a transformation of reality through research ${ }^{(20)}$. In the knowledge translation process, knowledge is created, disseminated and adopted into clinical practice. It becomes effective in nursing by means of strategies for the rapprochement between researchers (nurse researchers) and users (practicing nurses) ${ }^{(21-22)}$. This occurs through the identification of issues relevant to research, development of models for application of knowledge translation, as well as partnerships between researchers and users ${ }^{(23)}$.

Since it involves the interaction between researchers and consumers of knowledge, this is seldom a simple process. It has to surpass various barriers, whether individual or organizational. The individual barrier is perhaps the determining factor to facilitate or complicate such a dissemination of knowledge, since it involves changing human behavior.

The approach between university graduate courses and practice is essential, and efforts in this direction must be constant. Only in this way may research developed in nursing graduate courses effectively lead to changes in professional practice as well as in health policies. In an attempt to carry out this approximation, Brazil of the late 1990s witnessed the appearance of professional master's. Their main differential in relation to academic master's was the desired result, i.e., the research was expected to be inserted in the professional practice of the master's student, resulting in economic and social development ${ }^{(23)}$.

Such programs, which are growing in quantity and quality over the years, can collaborate to reduce the gap between research and practice ${ }^{(2)}$. In our study, we identified ten professional master's dissertations, a small amount compared to the total number of 216 studies analyzed. However, given the recent creation of these programs when compared to academic master's programs, we believe there is a strong likelihood that the amount of professional master's research on the topic of NDs will grow over the next few years, with results that will positively impact professional practice.
In addition to professional master's degrees, a type of research that in recent years is becoming increasingly popular in the area of nursing is translational research ${ }^{(24)}$. This method tends to act as a bridge between research results, and can provide new information about the effectiveness of nursing interventions, directly impacting care. This type of research, together with professional master's courses, can facilitate the filling in of gaps between scientific literature and health care practice.

Also central to the approximation of research and practice are the constant incentives of both advisors and the graduate programs themselves. Although our results have not shown significant practical application of knowledge about NDs by former students of nursing graduate courses, we believe that this knowledge has somehow been able to transform the practice of these researchers, guiding them and encouraging them to provide a more secure and improved assistance.

\section{Limitations of this study}

Our results should be analyzed in the light of their shortcomings, namely: search for DTs only in electronic archives; unavailability of some DTs defended in the period of interest, and the use of the perception of advisors as a measure of practical application of results both by themselves and their former students. In addition, almost $70 \%$ of invited nursing graduate program advisors did not participate in the study.

\section{Contributions to the field of nursing}

With this study's identification of the lacking practical application of research results, we believe that further studies are needed to identify barriers to the transposition of theory to practice. In this sense, professional master's programs and translational research could be opportunities to identify and overcome such obstacles.

\section{CONCLUSION}

There was a considerable increase of research on NDs by Brazilian nursing graduate programs in 2006; also, a great deal of research on NANDA-I NDs of the Safety/Protection domain was observed. The most studied population was the adult population, and few authors declared the use of nursing theoretical referentials for the development of their research. According to the perceptions of nursing graduate course advisors, the practical application of developed studies both by themselves and their graduates is somewhat insignificant, having a greater impact on graduate education itself.

\section{REFERENCES}

1. Lunney M. The Need for International Nursing Diagnosis Research and a Theoretical Framework. Int J Nurs Terminol Classif. 2008 Mar;19(1):28-34.

2. Scochi CGS, Munari DB. A pós-graduação em Enfermagem brasileira faz quarenta anos: avanços, desafios e necessidades de novos empreendimentos. Esc Anna Nery Rev Enferm [Internet]. 2012 Jun[cited 2017 Oct 21]16(2). Available from: http://www.redalyc.org/ pdf/1277/127722728001.pdf

3. Barros ALBL. Tendências da construção e translação do conhecimento sobre sistemas de classificação em enfermagem nas últimas décadas 
[Apresentação oral em: 12a Simpósio Nacional de Diagnóstico em Enfermagem; 2016 Jun 16; Recife, PE]

4. Silva VM, Oliveira TC, Damasceno MMC, Araújo TL. Languages of the nursing process in the dissertations and theses. A bibliographical study. Online Braz J Nurs [Internet]. 2006 Ago [cited 2016 Oct 3] ;5(2). Available from: http://www.objnursing.uff.br/index.php/nursing/article/ view/328

5. Assis AP. Proposição de um diagrama para realização de diagnósticos de enfermagem por iniciantes [Internet] Rio de Janeiro. Dissertação [Mestrado]. Universidade Federal do Rio de Janeiro - Escola de Enfermagem Anna Nery; 2010 [citado 21 de julho de 2017]. Available from: http://objdig.ufrj.br/51/teses/EEAN_D_AllanPeixotoDeAssis.pdf

6. Góes FSN. Desenvolvimento e avaliação de objeto virtual de aprendizagem interativo sobre o raciocínio diagnóstico em enfermagem aplicado ao recém-nascido pré-termo. [Tese de doutorado]. [Ribeirão Preto]: Universidade de São Paulo - Escola de Enfermagem de Ribeirão Preto; 2010.

7. Sousa VEC. Desenvolvimento e validação de software para apoio ao ensino-aprendizagem sobre diagnósticos de enfermagem. [Internet] Fortaleza. Tese [Doutorado]. Universidade Federal do Ceará; 2015. [cited 2017 Jul 18]. Available from: http://www.repositorio.ufc.br/handle/ riufc/12557

8. Benedet SA, Hermida PMV, Sell BT, Padilha MI, Borenstein MS. REBEn scientific production based on the nursing diagnosis: history of 2003 to 2010 Hist. enferm.; Rev. eletrônica. [Internet]2012 [cited 2017 Aug 31] ;3(2):125-40. Available from: http://www.usfx.bo/nueva/ vicerrectorado/citas/SALUD_10/Imagenologia/SA\%20BENEDET.pdf

9. Nóbrega MML, Garcia TR, Furtado LG, Albuquerque CC, Lima CLH. Nursing terminologies: the NANDA taxonomy to the International Classification for Nursing Practice. J Nurs UFPE Line. [Internet] 2008 Sep 25 [cited 2017 Aug 21] ;2(4):454-61. Available from: http://www. revista.ufpe.br/revistaenfermagem/index.php/revista/article/view/333

10. Brito MAGM. Diagnósticos de enfermagem da NANDA identificados em pessoas com lesão medular mediante abordagem baseada na teoria do déficit de autocuidado. [Internet] Goiânia. Dissertação [Mestrado]. Universidade Federal de Goiás; 2007 [cited 2017 Jul 21$].$ Available from: http://repositorio.bc.ufg.br/tede/handle/tde/769

11. Creason NS. Clinical Validation of Nursing Diagnoses. Int J Nurs Terminol Classif. [Internet] 2004 Oct 1 [cited 2017 Sep 4];15(4):123-32. Available from: http://onlinelibrary.wiley.com/doi/10.1111/j.1744-618X.2004.tb00009.x/abstract

12. Carpenito-Moyet LJ. Manual de diagnósticos de enfermagem. Porto Alegre: Artmed; 2008.

13. Vieira F. Diagnósticos de enfermagem identificados em puérperas no período imediato e tardio no contexto da comunidade [Internet] Dissertação [Mestrado]. Goiânia: Universidade Federal de Goiás; 2008 [cited 2017 Aug 21]. Available from: http://repositorio.bc.ufg.br/tede/ handle/tde/756

14. Fonseca SSO. Caracterização de puérperas e recém-nascidos e diagnósticos de enfermagem em alojamento conjunto [Internet]. Dissertação [Mestrado]. Campo Grande: Universidade Federal de Mato Grosso do Sul; 2014 [cited 2017 Aug 21]. Available from: http://repositorio.cbc. ufms.br:8080/xmlui/handle/123456789/2507

15. Trindade LR, Ferreira AM, Silveira A, Rocha EN. Nursing Process: challenges and strategies for its implementation from the nurses' point of view. Saúde St Maria. [Internet] 2016 [cited 2017 Apr 21];42(1):75-82. Available from: https://periodicos.ufsm.br/index.php/revistasaude/ article/view/19805

16. Silva VG. Protocolo de cuidados de enfermagem para crianças com cardiopatias congênitas: uma proposta baseada em NANDA-NOC-NIC. [Internet] Dissertação [Mestrado]. Niterói: Universidade Federal Fluminense; 2012. [cited 2017 Jul 20]. Available from: https://app.uff.br/riuff/ handle/1/1446

17. Souza JM. Desenvolvimento infantil: análise de conceito e revisão dos diagnósticos da NANDA-I. [Internet]Tese [Doutorado]. São Paulo: Universidade de São Paulo; 2014. [cited 2017 Sep 20]. Available from: http://www.teses.usp.br/teses/disponiveis/7/7141/tde-05112014115040/publico/DOUTORADO_JULIANA_MARTINS_DE_SOUZA.pdf

18. Brasil. ONU: Brasil cumpre meta de redução da mortalidade infantil [Internet]. Portal Brasil. [cited 2017 Aug 25]. Available from: http://www. brasil.gov.br/cidadania-e-justica/2015/09/onu-brasil-cumpre-meta-de-reducao-da-mortalidade-infantil

19. Brasil. IBGE - Pirâmide Etária - BRASIL - 2010 [Internet]. IBGE - Instituto Brasileiro de Geografia e Estatística. [cited 2017 Aug 31$]$. Available from: http://censo2010.ibge.gov.br/sinopse/webservice/frm_piramide.php

20. Depes VBS, Pereira WR. Mobilization of Scientific Knowledge by Graduates of a Nursing Master's Degree. Rev gaúcha enferm. [Internet]. 2013 Dec [cited 2017 Oct 31]34(4):84-90. Available from: http://www.scielo.br/scielo. php?script=sci_abstract\&pid=S1983-14472013000400011\&lng=pt\&nrm=iso\&tlng=pt

21. Crossetti MGO, Goes MGO. Knowledge translation: a challenge in providing nursing care. Rev gaúcha enferm [Internet]. 2017 Jun 23 [cited 2018 Mar 15];38(2). Available from: http://www.seer.ufrgs.br/index.php/RevistaGauchadeEnfermagem/article/view/74266/42013

22. Curtis K, Fry M, Shaban RZ, Considine J. Translating research findings to clinical nursing practice. J Clin Nurs [Internet]. 2016 Nov 22 [cited 2018 Mar 10];26(5-6):862-72. Available from: https://onlinelibrary.wiley.com/doi/abs/10.1111/jocn.13586

23. Scochi CGS, Gelbcke FL, Ferreira MA, Alvarez AM. Professional Master's Degree: potential contribution to Advanced Practice Nursing Rev bras enferm [Internet]. 2015 Dec [cited 2018 Feb 27] ;68(6):1186-9. Available from: http://www.scielo.br/pdf/reben/v68n6/0034-7167reben-68-06-1186.pdf

24. Cárnio EC. Translational research and nursing. Rev Lat Am Enfermagem [Internet]. 2012 Dec [cited 2018 Mar 10];20(6):1013-1013. Available from: http://www.scielo.br/pdf/tce/v20n3/01.pdf 